\title{
Assessment of the Online Teaching mode in the Subject of Geography at Undergraduate Level from Student's Perspective during the Academic Year 2020-21 : A Case Study \\ Dr. Kanchan Wani* \\ ${ }^{*}$ Department of Geography, Sir Parashurambhau College, Pune, Maharashtra, India
}

\begin{abstract}
Article Info

Volume 8, Issue 4

Page Number : 280-290

\section{Publication Issue}

July-August-2021

\section{Article History}

Accepted : 08 July 2021

Published : 15 July 2021

The COVID-19 is an ongoing global pandemic, caused by Severe Acute Respiratory Syndrome Coronavirus 2 (SARS-CoV-2). The virus was first identified in December 2019 in Wuhan, China. The COVID-19 pandemic in 2020 resulted in the abrupt shutting of all the educational institutions (schools, colleges, and universities) in India. This resulted in dramatic changes in the education system with the distinctive rise of e-learning, whereby teaching is undertaken remotely and on digital platforms. Online learning is a competent and contactless method of teaching to remotely located students.

Geography is a branch of science which deals with the study of the earth's surface and the relationships between people and their environment. Geographers explore both the physical properties of the earth's surface and the human societies spread across it. The subject matter of Geography containing different theory papers and practical papers cannot just be effectively taught in a classroom or laboratory but best enlightened on the field. For the effective learning process in the subject of Geography, students require on-ground observations, laboratory analysis, projects and dissertations, field surveying, computer mapping and analysis, field trips and excursions, etc. It helps the budding Geographers to acquire not only theoretical knowledge but also practical skills.

But the COVID-19 pandemic situation confronted the education system, forcing the educators in the field of Geography to shift to an online mode of teaching, leaving them with no option. During this crisis, the educators have given their best in teaching the subject matter of Geography to the students by using various open-source teaching aids by overcoming the issues like lack of training and professional technical support. This altered the traditional teaching and learning process in the field of Geography, which essentially affects the students of
\end{abstract}


Geography.

Thus, a case study was undertaken to assess the online teaching in the subject of Geography at the undergraduate level during the academic year 2020-21 from the student's perspective.

Keywords: COVID-19, pandemic, e-learning, technical, Geography, laboratory analysis, mapping and analysis, open-source, technology.

\section{INTRODUCTION}

The unexpected outbreak of a communicable disease called COVID-19 caused by a Corona Virus (SARS$\mathrm{CoV}-2$ ) shook the entire world. The outbreak was first reported in Wuhan, China, where a cluster of cases of pneumonia was recorded. A novel coronavirus was eventually identified. The World Health Organization declared it as a Public Health Emergency of International Concern on 30 January 2020 and later declared a pandemic on 11 March 2020 In India, the first case of COVID-19 was reported on 30 January 2020 at Thrissur, Kerala.

Since then, the COVID-19 cases started reporting and increasing in India. In the first week of March, the concerned authorities in various parts of the country, to control the spread of the pandemic temporarily closed all the educational institutions until further notice. The authorities have stated that conducting the physical classes for students will be dangerous and might result in a further surge in Covid-19 cases. Thus, there was an urgent need to protect and save the students, faculty, academic staff, communities, societies, and the nation as a whole, which led to the temporary closure of all the educational institutions in India. The COVID-19 pandemic clearly and utterly disrupted our education system. It enforced the shifting of traditional in-person and classroom teaching entirely to online teaching and learning. Thus, post-pandemic, online teaching started becoming the prime way to access education for students. The concept and experience of teaching and learning were transformed post-pandemic.

Geography is a branch of science which deals with the study of the earth's surface and the relationships between people and their environments. The subject matter of geography is inclusive of the description of the earth's surface, environment, human and interactions of humans with the environment. Geography has two principal branches: Physical geography and Human geography.

Physical geography studies the origin and distribution of natural features on the earth's surface and the earth's systems (atmosphere, hydrosphere, biosphere, and lithosphere) within a spatial or geographical reference frame. Physical geography can be further divided into many broad categories like Geomorphology, Climatology, Oceanography, Meteorology, Hydrology, Biogeography, Coastal geography, etc.

Human geography is concerned with the study of people and their communities, cultures, economies, and their interactions with the environment. Human geography studies the relationship between the physical earth and humans. Human geography can be further divided into many broad categories like Agriculture Geography, Social geography, Population 
Geography, Settlement Geography, Economic Geography, Tourism Geography, etc.

The dynamic and multidisciplinary nature of Geography has given rise to various techniques in geography like Cartography, Geographical Information System, Remote Sensing, Global Positioning System, etc. The subject of Geography can be studied and specialized in the Arts stream as well as in the Science stream. Geography as a subject includes theory as well as practical courses.

Geography as a subject has such rich and varied branches which can be taught and evaluated in form of theory papers, practical papers, surveying, laboratory analysis, computer-based mapping and analysis, project work, dissertation, field visits and report writing, modelling, etc.

Geography cannot be taught within the four walls of the classroom as it limits the teaching only to maps, globes, models, and books. So, the educators try to enhance the understanding of the subject of Geography among the students by adopting certain modes outside the classroom. Thus, it is clearly visible that the subject of Geography cannot be just taught in a classroom but requires various methods like the observation method, laboratory method, project method, regional method, and discussion method for best teaching and learning experience.

In developing countries like India, the issues of connectivity, affordability, lack of technology and skills, increase in screen time and its related problems are not only faced by the students as well as by the educators. Despite these issues, on a positive note, the pandemic has given educators from the urban to the rural setting, a new tool for expanding the teaching in the field of Geography. The professors started using, learning, and eventually shaping their expertise in recording audio-video lectures, video conferencing, collaborative tools, screen recording, and making presentations. They started making their online teaching process more interactive. Educators starting using various open-source tools like Zoom, Google Meet, Google Classroom, Google Forms, Google Jamboard, WhatsApp, KineMaster, YouTube, Microsoft Office, and many other types of software to make presentations, videos, study materials, conducting vivas and tests, collect assignments and projects and for other various essential tasks. Also, there were various training workshops conducted by the schools, colleges, universities, and other educational institutes which aimed to impart the knowledge of usage of Information Communication and Technology tools in teaching for their educators.

On the one side where the educational institutions and policymakers all over India are considering online mode suitable for continuing the teaching and examination in this adverse pandemic period, the problems at the student's end are also crucial. A few of the commonly experienced issues at the student's end are:

- Lack of device (mobile, tablet, laptop, desktop) for online mode of learning

- Many students face technical issues as they are not much aware of computer basics and were having issues in operating Microsoft Office which they were expected to use for submission of assignments, tests or project reports, especially in the subject of Geography.

- Lack of high-speed internet connection is essential for going live for virtual learning.

- Learning from one's home is the best and safest way during this pandemic. But, with online learning, there are many distractions as many of the students have small and crowded spaces at home. This is a serious issue that causes distractions, lack of concentration, inability to understand in live classes, and the learning process of many students get hampered.

- Due to lack of concentration, poor technological skills with computers and its application or 
inability to express themselves during live calls, students fail to respond to their educators when questioned.

- With these problems, students start losing their interest in the subject and find difficulty in online learning.

- These issues faced by the students during the online learning process have the risk of hampering the student's performance which is reflected in scores or grades and is essentially a major drawback of online teaching.

The educators have recognized these problems during the teaching-learning process, evaluation, viva, and examination. Educators thus need to constantly motivate their students to enhance and ease the process of online learning.

Despite all these difficulties, the universities and colleges all across India planned the academic year 2020-21 efficiently. The teaching of theory papers and practical papers also task of assigning the projects and dissertation work and the conduction of examination in form for multiple-choice questions, presentations and viva is being done for the undergraduate and postgraduate students. Concerning the subject like Geography, which essentially is a spatial science and also learned easily by observation, laboratory, project, and other methods, the teachers and professors were continuously trying to teach the subject by taking help of the videos, documentaries, websites, and other tools to improve the level of understanding in the students. The theory papers are being taught to the undergraduate and postgraduate students of geography by their educators in the online mode by taking the help of PowerPoint presentations, video recording, Jamboard, Google Maps, Google Earth, YouTube videos, and by using existing econtent available freely online. The online teaching of different theory papers in Geography was quite a difficult task but manageable too.
The main challenge faced by the educators in the field of Geography was teaching the practical papers to the graduate and post-graduate students of Geography. Some of the practical courses taught to the graduate and post-graduate students in the field of Geography are Map Analysis and Field Work, Spatial Analysis, Statistical Analysis, Geomorphological, and Soil Analysis, Practical in Surveying, Digital Image Processing, Practical in Geographical Information System, and Remote Sensing, Practical in Watershed Analysis and many others.

The practical papers in Geography before the pandemic were effectively taught in the offline mode in the college's laboratory, which is well equipped with maps, toposheets, chart papers, graph papers, satellite images, aerial photographs, instruments, computers and software, chemicals, stationery, and other things. The laboratory setup, available resources, hands-on experience, direct observation, etc helped the students to easily understand and effectually acquire the practical skills in Geography.

Thus, the practical, on-ground, and hands-on experience of handling the instruments, laboratory analysis, software mapping and analysis, surveying, etc is essential to deliver the practical knowledge and skills in the field of Geography. Following are the advantages of these traditional methods of offline teaching the practical papers in the field of Geography:

- Helps the students of geography to give hands-on instruments, experiments, software, and surveying techniques.

- Direct observation and data collection methods make the students of geography directly interact with the environment. This method of direct observation and experience among the student develops the habit of accurate investigation and conclusion. 
- These things effectively inculcate practical knowledge and practical skills among the budding geographers.

The COVID-19 pandemic completely changed these teaching methods in practical courses of Geography. But the subject experts and educators in the field of Geography starting making usage of the virtual platform to teach the same. Options like live demo and training, videos, screen recording, making use of online available videos, etc were made by the professors to clarify the concepts in the practical papers of Geography. Thus, the practical papers which are an indispensable part of Geography were taught in online mode to the students during this pandemic.

In order to explore the effectiveness of online teaching in the theory and practical courses of Geography at the undergraduate level from the student's perspective, a case study was undertaken. This case study focuses on understanding the satisfaction of students with online teaching mode of theory and practical papers of Geography, MCQ exam taken for evaluation of theory and practical papers of Geography, issues faced by students in the online mode of teaching, and whether the online teaching of the theory and practical papers of Geography gave the students holistic knowledge and practical skills?

\section{METHODS AND MATERIAL}

During the online teaching-learning process in the subject of Geography (theory and practical papers both) for the academic year 2020-21 for the undergraduate students, various issues were realized. By usage of open-source digital learning aids and ICT tools, some crucial changes were made in the process of teaching the subject of Geography in online mode and the learning process was tried to make it easier and more interactive.
During this period a need was felt to understand how has the undergraduate students perceived the online teaching of theory and practical papers in the subject of Geography. To get a new insight into this particular online teaching and learning phenomena in the field of Geography, a case study was conducted.

For the same, a survey was conducted, targeting Second-Year and Third-Year undergraduate students learning Geography in online mode for the academic year 2020-21. Total 130 undergraduate students from the Arts and Science stream from, The Department of Geography, Sir Parashurambhau College, Pune-30, participated in the survey. Fig. 1 and Fig. 2 show the classification of the number of students who participated in the survey based on the year and stream of graduation respectively.

\section{TOTAL NUMBER OF PARTICIPANTS}

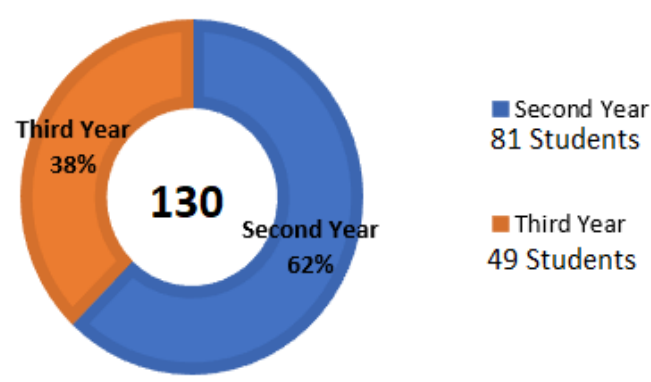

Figure 1: A chart showing number of participants in the survey based on the year of graduation.

\section{TOTAL NUMBER OF PARTICIPANTS}

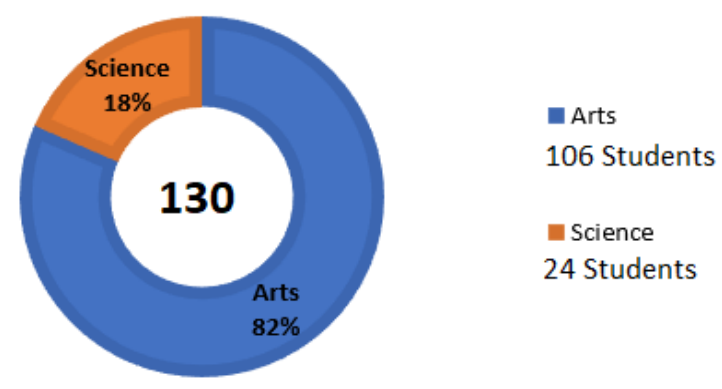

Figure 2: A chart showing number of participants in the survey based on the stream of graduation 
For the same, a questionnaire was tailored which aimed to collect the required data and was distributed among the participants. Due to the current pandemic situation and closure of the college, the survey was conducted in online mode with the help of Google Forms.

Following crucial and student-centric questions are included in the questionnaire (only for the academic year 2020-21) :

- Students' satisfaction with the online teaching of theory and practical papers in Geography.

- Which is the suitable way for students to understand the theory and practical papers in Geography?

- Was the online exam taken in the form of Multiple-Choice Questions in the subject of Geography for the theory and practical papers, a correct pattern of examination in this COVID-19 pandemic?

- Is online teaching of Geography theory and practical papers, a holistic approach to gain full knowledge of the subject?

- Issues faced by the students while learning Geography (both theory and practical courses) in online mode.

- Is the field visit/ study tour which is included in the syllabus of Geography, is essential and helps students in better understanding of the subject?

The collected responses are subsequently analysed to interpret the results.

\section{III.RESULTS AND DISCUSSION}

Following is the analysis of the parameters considered for the case study and discussion of the outcomes:

A. Student's satisfaction with the online teaching of theory and practical papers in the subject of Geography (for the academic year 2020-21):

\section{STUDENTS SATISFACTION WITH THE ONLINE TEACHING OF THEORY PAPERS OF GEOGRAPHY}

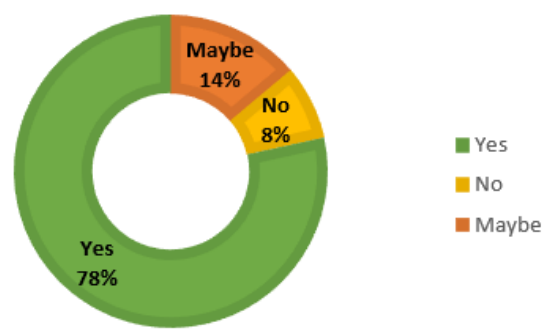

Figure 3: Chart showing percentage of student's satisfaction with the online teaching of theory papers of geography

Fig. 3 shows that $78 \%$ (102 students) of the 130 students are satisfied and comfortable with learning geography theory papers online. Only, 8\% (10 students) are unsatisfied while 14\% (18 students) are unsure that whether the subject of geography was satisfactorily taught and learned in the online mode or not.

This ensures that when the pandemic occurred, the online teaching and learning methods adopted for the undergraduate Geography courses operated satisfactorily for explaining concepts and clarifying doubts. It continued the teaching and learning process despite the ongoing pandemic.

Out of 130 students as shown in Fig. 4, the majority i.e., 56\% (73 students) are dissatisfied with learning practical concepts in geography in the online mode. Whereas, only 35\% (46 students) are at ease of understanding and learning the practical papers geography through the online mode.

\section{STUDENTS SATISFACTION WITH THE ONLINE TEACHING OF PRACTICAL PAPERS OF GEOGRAPHY}

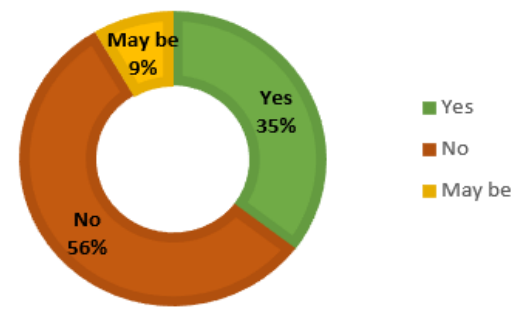

Figure 4 : Chart showing percentage of student's satisfaction with the online teaching of practical papers of geography 
This evidently shows that the practical courses in the subject of geography cannot be completely taught in the online mode, but requires the students to get exposed to hands-on experiences, on-site observations, laboratory analysis, on-ground surveying, computerbased mapping, etc. These activities essentially cannot be provided in online mode.

B. Which is the suitable way for students to understand the theory and practical papers in Geography?

\section{WHICH IS THE SUITABLE WAY TO UNDERSTAND THE THEORY PAPERS IN GEOGRAPHY}

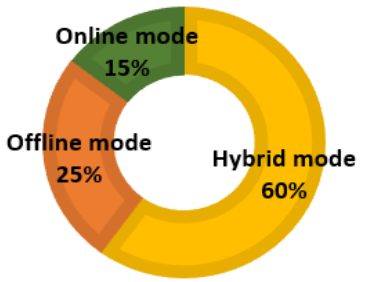

Hybrid mode (online and offline together)

- Offline mode

- Online mode

Figure 5 : Chart showing percentage of student's

liking of a suitable mode for the understanding of theory papers of geography

Fig. 5 illustrates that a majority of students $60 \%$ (78 students) believe that a hybrid teaching approach comprising online and offline instruction will make geography theory courses more understandable. While $25 \%$ of students (33 students) liked the previous offline and classroom teaching method of geography. Out of 130 students, 15\% (19 students) were comfortable with a complete online understanding of theory papers in geography.

In terms of learning Geography theory courses, most students preferred the hybrid mode since some concepts can be learned easily online, but the online mode cannot cover all advantages of classroom, laboratory, analyses, and observations teaching. The offline mode gives liberty to observation and correlation and facilitates better learning of geography, which is a spatial science.

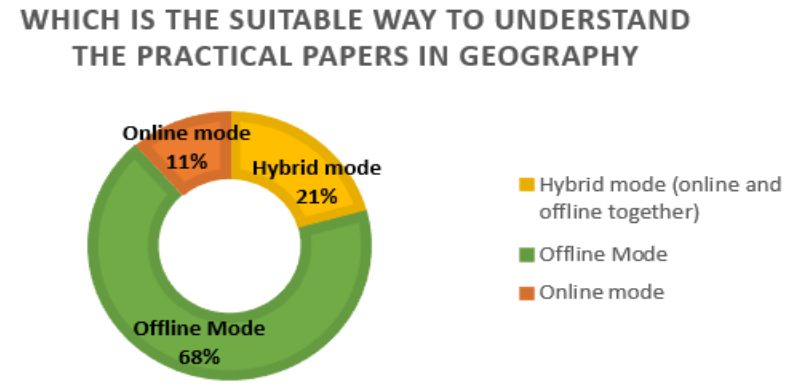

Figure 6: Chart showing percentage of Student preferences for different modes of understanding practical papers in geography.

The practical courses in geography are taught by making use of observation method, project, laboratory analysis, on-ground surveying, hands-on experiences on instruments, software, etc. Thus, it requires a wellequipped laboratory to deliver complete knowledge of the practical courses in geography. In essence, the practical courses in the subject of geography cannot be taught holistically in an online mode only.

This aspect was reassured in the survey, as shown in Fig. 6, out of 130 students, the majority i.e., $68 \%$ of students (88 students) wanted the practical papers in geography to be conducted in the offline mode. While only $11 \%$ of the survey students (15 students) were comfortable in online teaching and learning of the practical papers in geography. $21 \%$ of total students (27 students) felt that hybrid mode will also be a suitable option in learning the practical skills in geography.

C. Was the online exam taken in the form of Multiple-Choice Questions in the subject of Geography for the theory and practical papers, a correct pattern of examination in this COVID-19 pandemic? 
WAS THE ONLINE EXAM TAKEN IN THE FORM OF MCQ IN THE SUBJECT OF GEOGRAPHY FOR THE THEORY PAPERS, A CORRECT PATTERN OF EXAMINING IN THIS COVID-19 PANDEMIC?

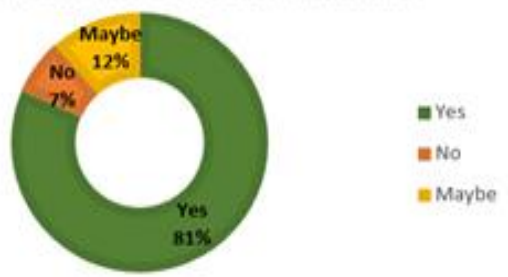

Figure 7: Chart showing in this COVID-19 pandemic, is the online exam taken in the form of multiplechoice questions for theory papers in the subject of geography a valid pattern of examination?

Fig. 7 depicts that, $81 \%$ of the total surveyed students (106 students) feel that the online exam taken in of Multiple-Choice Questions form for the theory courses in geography is the ideal way of evaluation. Only $7 \%$ of the total students (9 students) supported the traditional method of examination involving offline mode of examination comprising of short and essay type of questions, computational questions, etc. $12 \%$ of the total students (15 students) are in dilemma of deciding whether the online examination taken in the theory courses of geography in multiple-choice questions correctly evaluated them or not.

WAS THE ONLINE EXAM TAKEN IN THE FORM OF MCQ IN THE SUBJECT OF GEOGRAPHY FOR THE PRACTICAL PAPERS, A CORRECT PATTERN OF EXAMINING IN THIS COVID-19 PANDEMIC?

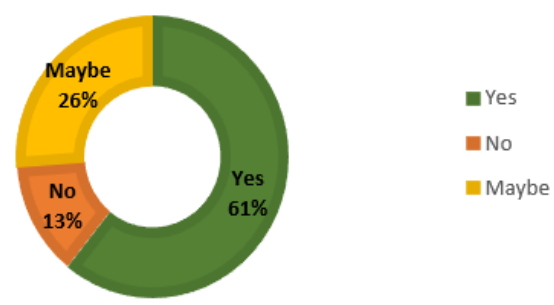

Figure 8: Chart showing in this COVID-19 pandemic, is the online exam taken in the form of multiplechoice questions for practical papers in the subject of geography a valid pattern of examination?

The traditional and offline method of examination in the practical courses of the geography involved question paper comprising of fill in the blanks, true or false, short and essay type of questions, computational questions, surveying, mapping, soil analysis, viva, toposheet, and satellite image interpretation, etc. But in the online mode of practical examination in geography, the format was fixed to multiple-choice questions and viva. This method of evaluation in practical papers of geography got different reactions as compared to the theory papers.

Fig. 8 shows that $61 \%$ of the total surveyed students (79 students) feel that the online exam taken in of Multiple-Choice Questions form for the practical courses in geography is the ideal way of evaluation. While $26 \%$ of the total students (34 students) were unsure about the MCQ paper pattern for practical examinations in geography. $13 \%$ of the total surveyed students (17 students) still backed the traditional way of evaluation in the practical courses of geography.

D. Is online teaching of Geography theory and practical papers, a holistic approach to gain full knowledge of the subject?

ONLINE TEACHING OF GEOGRAPHY THEORY PAPERS, A HOLISTIC APPROACH TO GAIN FULL KNOWLEDGE OF THE

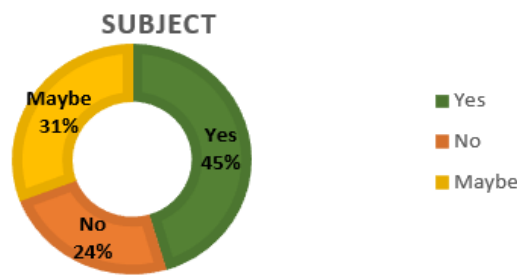

Figure 9: Chart showing whether the online teaching of Geography theory papers, a holistic approach to gain full knowledge of the subject?

During the critical period of the pandemic, when the theory courses of Geography were taught in online mode to the undergraduate students, only $45 \%$ of the total surveyed students (59 students) agreed that online teaching of the theory papers of Geography is a holistic way of teaching and learning and gaining complete knowledge of the subject, as shown in Fig. 9. While $31 \%$ of the total surveyed students ( 40 students) were still in the dilemma of whether the online teaching mode of theory papers in Geography gave 
them a complete exposure to Geographical knowledge. $24 \%$ of the total surveyed students (31 students) still think that the online teaching approach of the theory paper of Geography was unable to give complete knowledge of the subject.

This paved a way that, for teaching and learning the theory papers in Geography, online mode is not selfsufficient but also requires the help of offline mode for the best experience.

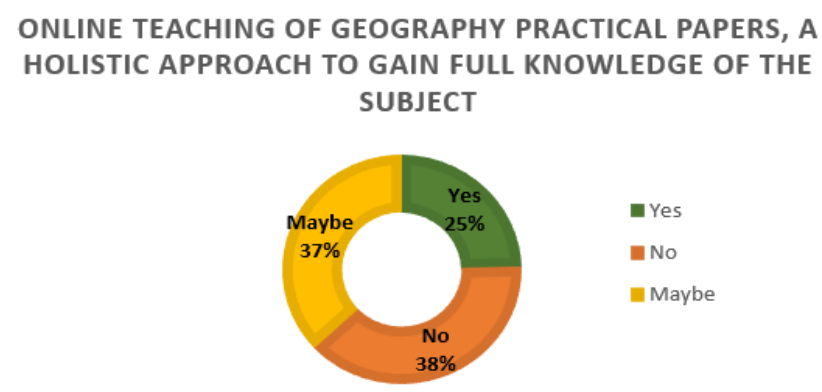

Figure 10: Chart showing whether the online teaching of Geography practical papers, a holistic approach to gain full knowledge of the subject?

The results for the survey for online mode in teaching practical courses in the subject of Geography, came out completely different from that of theory courses. Fig. 10 shows that the majority of the surveyed students, i.e., $38 \%$ (50 students) feel that online teaching of practical papers in Geography is not a holistic approach to gain full knowledge and acquire practical skills. Only $25 \%$ of the total surveyed students (32 students) feel that online mode can deliver complete practical skills and knowledge in the subject of Geography. 37\% of the total surveyed students (48 students) are in a dilemma of demarcating that whether the online mode of teaching of practical courses in the subject of Geography delivered the complete knowledge or not.

These findings support the inclusion of the offline mode of teaching the practical courses of Geography, which essentially deliver the practical skills in Geography by utilizing the instruments, laboratory analysis, software mapping, field survey, field excursions, etc.

E. Issues faced by the students while learning Geography (both theory and practical papers) in online mode.

\section{ISSUES FACED BY STUDENTS WHILE ONLINE LEARNING IN GEOGRAPHY SUBJECT}
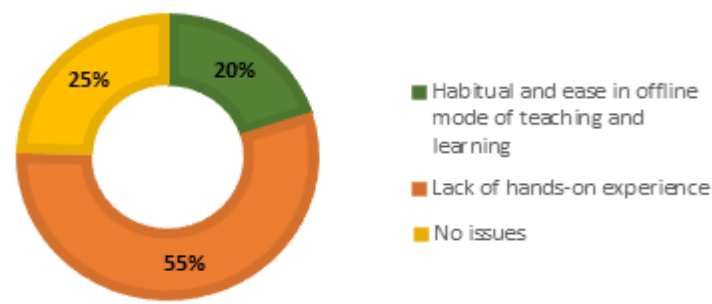

Figure 11: Chart showing issues faced by the students while online learning the theory and practical paper in the subject $t$ of Geography.

Fig. 11 depicts that the majority i.e., 55\% of the surveyed students (72 students), faced the issue of lack of hands-on experience on aids like maps, toposheets, weather instruments, survey instruments, laboratory analysis, software, etc. while studying the theory and practical course in Geography. Majorly these aids are made available to the students in the geography laboratory, which is well equipped with the required materials providing help in the teaching and learning process. Very few of the materials like maps, toposheets, aerial photographs, satellite images, diagrams and pictures of instruments, etc can be shown by the educators in the online mode of teaching. 20\% of the surveyed students (26 students) agreed that they are habitual with the offline mode of teaching and learning and are still in the process of acclimatization with the online mode. Only $25 \%$ of the total surveyed students (32 students) faced no issues while learning the subject of Geography in online mode.

This aspect highlights the importance of observation and practical experience in the teaching and learning process in the subject of Geography. 
F. Is the field visit/ study tour which is included in the syllabus of Geography, is essential and helps students in better understanding of the subject?

\section{DOES FIELD EXCURSIONS HELPS IN LEARNING PROCESS?}

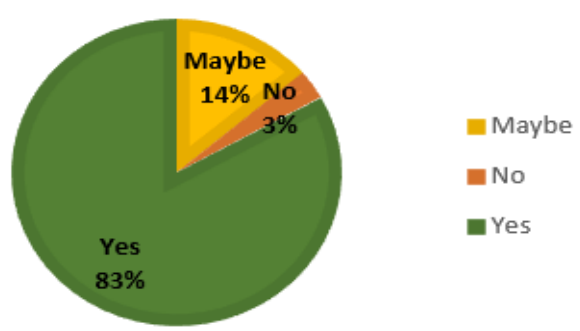

Figure 11: Chart showing the importance of field excursions in the learning process of Geography.

Field excursions and study tours are an inseparable component of the teaching and learning process in the theory as well as practical courses of Geography. They provide an opportunity for direct observations and correlation, which simplifies the learning process for the geographers. Thus, field visits are included in the curriculum of Geography. Owing to the Covid-19 pandemic, no field visits were conducted in the academic year of 2020-21.

Fig. 11 portrays that the majority of the surveyed students i.e., 83\% (108 students) feel that field visits help them in better understanding of the subject. While only $3 \%$ of the total surveyed students (4 students) feel that study tour and field excursion, included in the curriculum is not that supportive in the learning process. $14 \%$ of the total surveyed students (18 students) were unable to decide the role of field excursions in the learning process of Geography.

\section{IV.CONCLUSION}

The current pandemic completely changed the traditional methods of teaching the theory and practical papers of Geography which involves observations, projects, computer mapping and analysis, laboratory analysis, field surveying, etc. along with classroom teaching and learning. The teaching for the academic year 2020-21 was conducted completely in online mode for theory and practical courses in the subject of Geography.

Thus, in order to assess the student's perspective on the online teaching mode in the subject of Geography, a case study was undertaken which highlighted some of the key findings, which will, in turn, help the educators to modify the teaching and learning process.

Concerning the theory courses in Geography at the undergraduate level, $78 \%$ of students are satisfied with the teaching of geography theory papers in online mode, but only $45 \%$ of students agreed that online teaching of the theory papers of Geography is a holistic way of teaching and learning and gaining complete knowledge of the subject. $60 \%$ of students feel that hybrid mode comprising of online and offline teaching is the easier and better way to understand the theory courses of geography.

For the practical courses in Geography, 56\% of students are dissatisfied with learning practical concepts in geography in the online mode and $38 \%$ of students feel that online teaching of practical papers in Geography is not a holistic approach to gain full knowledge and acquire practical skills. The majority i.e., $68 \%$ of students want the practical papers in geography to be conducted in the offline mode.

Also, $83 \%$ of the students felt that field excursion aids in an easy and effective learning process in Geography, which was not conducted in the academic year 2020-21 due to restrictions in the pandemic.

This calls for an urgent need for educators in the field of Geography to come up with a hybrid mode of teaching in the theory giving more emphasis on the offline mode for the practical courses in Geography. This will ease the process of learning and understanding the subject among the budding 
geographers, giving them hands-on experience on instruments, analysis, mapping, field visits and observations, surveying, maps, toposheets, satellite images, aerial photographs, models, charts, etc., But this hybrid mode of teaching should cater the health and safety of students and educators too.

\section{REFERENCES}

[1]. https://ddceutkal.ac.in/Syllabus/MA_Education/ Education_Paper_5_GEOGRAPHY.pdf

[2]. https://www.weforum.org/agenda/2020/04/coro navirus-education-global-covid19-online-

digital-learning/

[3]. https://journals.sagepub.com/doi/full/10.1177/0 047239520934018

[4]. https://www.who.int/docs/defaultsource/coronaviruse/situationreports/20200423-sitrep-94-covid-19.pdf

[5]. https://www.ncbi.nlm.nih.gov/pmc/articles/PM C7530459/

[6]. https://www.news18.com/news/india/toprevent-covid-hotspots-in-schools-maha-areasshut-down-schools-colleges-heres-the-full-list3527858.html

[7]. https://www.indiatoday.in/educationtoday/news/story/mumbai-colleges-to-remainclosed-as-covid-19-cases-rise-in-maharashtra1776296-2021-03-06

[8]. Beth McMutrie and Beckie Supiano. 2021. The Chronicle of Higher Education. (May 2021). Online edition

\section{Cite this article as :}

Dr. Kanchan Wani, "Assessment of the Online Teaching mode in the Subject of Geography at Undergraduate Level from Student's Perspective during the Academic Year 2020-21 : A Case Study", International Journal of Scientific Research in Science and Technology (IJSRST), Online ISSN : 2395-602X, Print ISSN : 2395-6011, Volume 8 Issue 4, pp. 280-290, July-August 2021. Available at doi : https://doi.org/10.32628/IJSRST2183111

Journal URL : https://ijsrst.com/IJSRST2183111 